\title{
ИНСТИТУЦИОНАЛИЗАЦИЯ
}

РЕГИОНАЛЬНОГО ПРОСТРАНСТВА РФ

DOI: https://doi.org/10.15688/jvolsu4.2021.3.18

UDC 321.01

LBC 66.3(2Poc)5

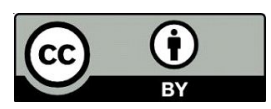

Submitted: 26.08 .2020

Accepted: 22.01.2021

\section{RUSSIAN ETHNOFEDERALISM: EVOLUTION AND DEVELOPMENT PROSPECTS ${ }^{1}$}

\author{
Valery A. Achkasov \\ Saint Petersburg State University, Saint Petersburg, Russian Federation \\ Anna I. Abalian \\ Saint Petersburg State University, Saint Petersburg, Russian Federation
}

\begin{abstract}
Introduction. The authors analyze the peculiarities of the formation, evolution and prospects of Russian ethnofederalism, based on the achievements of Russian and Western researchers. Methods and materials. Along with classical approaches to the nature of ethnofederalism, the authors proceed from the concept that relations between the elites of the center and the regions in the Russian Federation are based on the so-called "incomplete contract", which is characterized by the absence of guarantees for its implementation. Analysis. This political practice comes as a source of the elites desire to change the distribution of power and resources in their favor while the Constitution remains unchanged, the "pendulum" nature of relations along the "federal center regions" line. In modern Russia federalism does not have a value dimension, both for the elites of the center and the elites of most regions, and it remains a purely instrumental concept. The authors build their analysis of interethnic relations and the prospects of ethnic federalism in Russia, proceeding not from any ideal model, but starting from the existing ethnic political reality with its already existing imperfect institutions of ethnic federalism. At the same time, a differentiated approach is used to assess the correlation between federalism and ethnicity. Results. The authors come to the conclusion that, despite the numerous shortcomings of the ethnic model of federalism (organizational complexity, special requirements for political elites, asymmetry with its inherent "injustice", etc.), there is no real alternative to it in Russia.
\end{abstract}

Key words: Russian ethnofederalism, institutions, center - regions, structural asymmetry, political elites, concept of "incomplete contract".

Citation. Achkasov V.A., Abalian A.I. Russian Ethnofederalism: Evolution and Development Prospects. Vestnik Volgogradskogo gosudarstvennogo universiteta. Seriya 4. Istoriya. Regionovedenie. Mezhdunarodnye otnosheniya [Science Journal of Volgograd State University. History. Area Studies. International Relations], 2021,

\section{РОССИЙСКИЙ ЭТНОФЕДЕРАЛИЗМ: СТАНОВЛЕНИЕ И ПЕРСПЕКТИВЫ РАЗВИТИЯ ${ }^{~}$}

\section{Валерий Алексеевич Ачкасов}

Санкт-Петербургский государственный университет, г. Санкт-Петербург, Российская Федерация 


\section{ИНСТИТУЦИОНАЛИЗАЦИЯ РЕГИОНАЛЬНОГО ПРОСТРАНСТВА РФ}

Анна Игоревна Абалян

Санкт-Петербургский государственный университет, г. Санкт-Петербург, Российская Федерация

Аннотация. Введение. Статья посвящена особенностям формирования, эволюции и перспективам российского этнофедерализма. Mетоды и материаль. Наряду с классическими подходами к исследованию сущности этнофедерализма авторы исходят из теоретического положения, что современное российское федеративное государственное устройство и в первую очередь отношения между элитами центра и регионов основаны на так называемом «неполном контракте», который характеризуется отсутствием гарантий исполнения политических решений. Анализ. Данную политическую практику отличают стремление элит изменить распределение власти и ресурсов в свою пользу при неизменности Конституции, «маятниковый» характер отношений по линии «федеральный центр - регионы» (стихийная децентрализация власти в 1990-е гг. и ее централизация в 2000-е гг.). В России федерализм является понятием сугубо инструментальным, которое не имеет ценностного измерения как в восприятии политических элит центра, так и большинства регионов. Авторы основывают свой анализ межэтнических отношений и перспектив этнофедерализма в России исходя не из некой идеальной модели, а отталкиваясь от существующей этнополитической реальности и учитывая особенности уже существующих несовершенных институтов этнофедерализма. В основу анализа положен дифференцированный подход к оценке соотношения федерализма и этничности: в каких случаях учет этнического фактора в структуре федерации крайне необходим, а в каких он способен сыграть разрушительную роль. Учитывается и ряд других факторов: степень демократичности отношений центр - регионы, уровень экономического и социального развития регионов, этнический состав населения, характер исторически сложившихся межэтнических отношений и т. д. Результаты. Авторы приходят к заключению, что, несмотря на многочисленные недостатки этнической модели федерализма (организационная сложность, особые требования, предъявляемые к политическим элитам, асимметричность с присущей ей «несправедливостью» и др.), реальной альтернативы данной модели в России не существует. Вклад авторов. В.А. Ачкасову принадлежит разработка теоретической базы исследования, проблематики особенностей модели российского этнофедерализма, соотношения федерализма и этничности, структурной асимметрии, характеристики политических элит. А.И. Абалян - разработка методологии исследования, проблематики взаимоотношений «центр регионы», конфликтогенного потенциала модели этнофедерализма.

Ключевые слова: российский этнофедерализм, институты, центр - регионы, структурная асимметрия, политические элиты, концепция «неполного контракта».

Цитирование. Ачкасов В. А., Абалян А. И. Российский этнофедерализм: становление и перспективы развития // Вестник Волгоградского государственного университета. Серия 4, История. Регионоведение. Международные отношения. - 2021.-T. 26, № 3.-C. 203-216. - DOI: https://doi.org/10.15688/jvolsu4.2021.3.18

Введение. Согласно Основному Закону Российская Федерация состоит из республик, краев, областей, городов федерального значения, автономной области, автономных округов. Непреложным условием взаимоотношений субъектов РФ с федеральными органами государственной власти является их равноправие по отношению друг к другу. Между тем в составе России сегодня 22 республики, 1 автономная область, 4 автономных округа, то есть из 85 субъектов Федерации - 27 сформированы по этнотерриториальному принципу. Если мы сравним собственно «национальные» субъекты Российской Федерации по целому ряду оснований, то зафиксируем не только их разнообразие, но и фактическое неравенство. Так, в состав РФ входят самое большое национально-территориальное образование в мире - Республика Саха (Якутия) - более 3 млн км², и один из самых маленьких субъектов - Республика Ингушетия - немно-

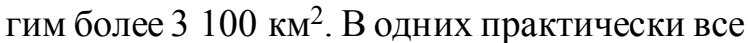
население принадлежит к «титульной» этнической группе (Чечня, Ингушетия), в других подавляющее большинство населения - представители не «титульных» народов (в Карелии, Ханты-Мансийском и Ямало-Ненецком автономных округах такого рода группы составляют менее 10 \% всего населения). Кардинальные различия между регионами существуют и по уровню социально-экономического развития. Так, по показателю ВВП на душу населения, самыми богатыми субъектами РФ являются Ямало-Ненецкий и Ханты-Мансийский $\mathrm{AO}$, а самым бедным - Республика Ингушетия: показатели ВВП на душу населения различаются в 40 раз. Значительно варьируется степень гетерогенности и численность 
населения «национальных» субъектов РФ, характеристики региональных политических режимов, неформальные правила, на основании которых они взаимодействуют с Федеральным центром и т. д. Совокупность вышеизложенных факторов обусловливает особую сложность решения проблем, связанных с формированием общей идентичности, преодолением социально-экономического неравенства регионов и сохранением стабильности функционирования асимметричной этнофедерации в условиях современной России.

Методы. Этнофедерализм мы рассматриваем как систему, обладающую эффективными механизмами интеграции интересов больших политических общностей, способных к обеспечению собственной безопасности и экономического развития, с одной стороны, и политических образований, которые представляют национальные меньшинства и локальные интересы. Функционирование данной модели обеспечивается разделением властных полномочий и сфер ответственности между центральными и местными органами власти. В то же время сама система способна порождать и поддерживать конфликты, угрожающие существованию этой политии. Парадоксальность федеративного устройства, обладающего одновременно как потенциалом сдерживания сецессионизма, так и его провоцирования, отмечена Я. Эрком и Л. Андерсоном [35].

Дискуссия о природе этнофедерализма идет уже достаточно давно, однако на современном этапе она протекает под влиянием глобальных трансформаций на мировой арене, сформировавших противоположные взгляды на эффективность и жизнеспособность этнофедеративной модели [32; 39]. Формирование одной точки зрения обусловлено становлением мультинациональных государств, где этнофедерализм использовался как политическая стратегия сохранения целостности политии (Бельгия, Индия, Канада) [25; 33; 36; 38; 42]. Другой подход основан на практическом опыте распада Советского Союза, Югославии и Чехословакии, поставившем под сомнение стабильность и долговечность мультиэтничных федераций $[1 ; 29 ; 31 ; 37 ; 39]$. Целью настоящего исследования является оценка особенностей становления и перспектив модели этнофедерализма в современной России с точ- ки зрения ее эффективности и устойчивости к конфликтам.

Анализ. В 1990-х гг., когда федеральная власть была слаба, она особенно нуждалась в поддержке политических элит регионов. Россия, как тогда казалось, находилась на грани распада, прежде всего, в результате перманентного неформального торга элит центра и национальных республик по вопросам перераспределения властных, финансовых и иных ресурсов. «Децентрализация того периода была обусловлена не целенаправленной политикой федерального центра или требованиями субъектов федерации, а слабостью общенационального правительства, не обладавшего возможностью контролировать территорию страны и эффективно сопротивляться “региональной вольнице"» [21, с. 101]. Подобная слабость центральной власти обусловила фрагментацию правового пространства страны. Согласно данным Министерства юстиции РФ на 1997 г. 16000 законов субъектов Федерации не соответствовали Конституции России. Именно те регионы, в особенности ряд национальных республик, где законы в наибольшей степени не соответствовали федеральным законам и Конституции, центр пытался «подкупать» [41, p. 90]. Очевидно, именно существующая автономия регионов представляла наибольшую опасность для центральной власти. Асимметричность российского федерализма достигла апогея в период 19941998 гг., когда широкое распространение получила практика заключения двухсторонних соглашений Центра с отдельными субъектами Федерации о разграничении полномочий и предметов ведения органов государственной власти. Фактически происходила трансформация конституционной федерации в договорную. Подобный переход задумывался первоначально как механизм выстраивания отношений с «проблемными» республиками - Татарстаном и Чечней, а также с Калининградской областью, с ее эксклавным положением. «...Такого статуса стали добиваться самые энергичные руководители других республик и областей, и в результате процесс превратился в опровержение своих первоначальных целей. Ведь на старте предполагалось дать особый статус тем регионам, с которыми договора заключались, причем имелось в виду, дать его счи- 
танному числу субъектов. Процесс же вскоре стал массовым. В результате из 89 субъектов РФ - 46 начали строить с Центром особые отношения» $[19$, с. 91-92].

Справедливости ради нужно заметить, что фактически ни один из субъектов РФ, за исключением Чечни, не был в действительности настроен на сецессию, однако угрозы такого рода использовались для шантажа федеральной власти. В результате в 1990-е гг. было заключено 46 двухсторонних договоров и около 300 соглашений, закрепляющих за субъектами Федерации (и, прежде всего, национальными республиками) различного рода экономические и финансовые преференции, что, в свою очередь, укрепляло их политическую автономию от Центра [13].

Подводя итоги строительства российского федерализма в 1990-е гг., Н.В. Петров выделил ряд факторов, негативно повлиявших на этот процесс $[17$, с. 8-9]. Одни из них обусловлены предшествующим историческим периодом развития российской государственности. Речь идет как о смешанном, экстерриториальном характере субъектов Федерации, когда этническое и территориальное начала, дополняя друг друга, создавали кумулятивный эффект, потенциально усиливавший уровень конфликтности, так и о гипертрофии центров любого уровня, плохо сочетавшейся с принципом равноправия. Другие факторы определяются особенностями постсоветского государственного развития. Таковыми являлись значительное неравенство потенциалов и статусов субъектов Федерации и продолжающийся рост неравенства регионов в социальноэкономическом и политическом отношениях.

Современные регионы отличались крайней слабостью горизонтальных связей, привязанностью граждан к территории проживания, препятствующей перемещению рабочей силы и ограничивающей возможности выравнивания темпов развития регионов. Инициированный «сверху» характер российского федерализма характеризовался отсутствием собственного ценностного измерения: в республиках развитое региональное самосознание, как правило, заменялось акцентированной этнической идентичностью. Фиксировалось противоречие между «суперпрезидентством» (де-факто закрепленным в Конститу- ции РФ) и слабостью центра в отношениях с субъектами Федерации. Отмечалась чрезмерная роль субъективного фактора, когда личностные качества главы субъекта Федерации и его личные связи во многом определяли и отношения с центром, и развитие политической ситуации в регионе. Имело место сращивание политической власти с собственностью; при отсутствии реального разделения ветвей власти такая ситуация делала главу исполнительной власти региона доминирующей фигурой, в то время как возникающие политические конфликты оказывались тесно связанными с борьбой за передел собственности.

Вместо открытой, публичной, политики, пользующейся поддержкой различных групп населения, доминировали неформальные правила игры. Региональное законодательство радикально не соответствовало федеральному: около $70 \%$ законодательных актов субъектов Федерации содержали определенные отклонения от общероссийских, а в 30-40\% случаев напрямую противоречили Конституции и общефедеральным законам. Кроме того, некоторые автономные округа входят в состав других субъектов РФ, что создает специфическую многоуровневую («матрешечную») структуру Федерации. Включение одного субъекта в состав другого служит очевидным примером нарушения принципа равноправия, закрепленного в Конституции РФ.

Очевидный факт, что население практически всех национальных регионов в России мультиэтнично. Однако вследствие того, что титульный этнос выступает в качестве субъекта национально-государственного суверенитета, именно он обладает эксклюзивным правом на самоопределение, вне зависимости от полиэтничности состава населения республики или округа его расселения. Статусы «гражданина» и «члена этнической группы» представляются не в качестве «взаимосвязанных социальных позиций личности» - «в рамках единого сообщества», а «противостоящими друг другу социальными категориями». Такого рода диспозиция вызывает разговоры о необходимости предоставления неких «особых» политических, экономических, культурных прав титульным группам в ущерб интересам остальных граждан; негативную роль при этом играет тезис о том, что «титульные 
группы являются коренным, то есть исконным населением того или иного региона, а потому имеют особые права на земельные ресурсы, природные богатства, политический и социальный статус» [27, с. 49].

Предоставление «титульным этносам» права на политическую автономию послужило основой для возникновения целого ряда противоречий, с которыми сталкиваются национально-территориальные федерации. Означает ли факт принадлежности субъекта Федерации к «титульной» национальности одновременным исключением его из числа «своих» остальными гражданами данного региона? В случае, если государственность выступает для них также «своей», какое значение имеют заявления о ее этнической «принадлежности»? Если подобные декларации не ограничиваются лишь символической значимостью, в каких институтах и отношениях находит выражение связь между этничностью и территорией? [16, с. 150-151]. Не случайно многие исследователи негативно характеризуют корреляцию между практикой этнофедеративных систем и реализацией так называемых «либеральных ценностей».

В 2000-е гг. маятник российского федерализма резко пошел в направлении централизации посредством реализации политики «укрепления вертикали власти». Новый курс нашел выражение в целом цикле административных реформ, радикально изменивших «правила игры», но осуществленных без изменения российской Конституции. Однако необходимо отметить, что некоторые правовые основания для такого перераспределения властных полномочий существуют, поскольку в Конституции России нет такого понятия, как собственные или исключительные предметы ведения субъектов Федерации. Исследователи справедливо отмечают, что если в соответствии с федеральным законодательством некая сфера деятельности относится к ведению субнационального уровня, а на практике является частью совместных предметов ведения, в таком случае «субъект федерации обладает собственной волей лишь до тех пор, пока соответствующим вопросом не заинтересуются федеральные власти», потому как только «центр определяет те направления, по которым региональные власти могут прини- мать окончательные решения, а также те правила, которых они обязаны придерживаться» $[22$, с. 87].

Казалось бы, в результате реформ была создана «единая административная система, работающая как один организм» [6], однако сделано это было за счет серьезного урезания властных полномочий и финансовых возможностей субъектов Федерации. Иностранные эксперты считают, что лучшим индикатором степени автономии, которой пользуются регионы, может быть пропорция публичных расходов, находящаяся под контролем соответствующих уровней власти [40]. В 2000-е гг. в России централизация имела место не только в политике, но и бюджетной сфере. Так, со второй половины 2000-х гг. стал целиком направляться в федеральный бюджет налог на добычу полезных ископаемых («нефтяная рента»), который до этого распределялся между Центром и регионами. Если в начале нового тысячелетия доходы федерального бюджета и консолидированных бюджетов регионов соотносились в пропорции 50 : 50, то в 2013 г. 61 : 39 [11, с. 369]. В свою очередь, система трансфертов, направленная на выравнивание бюджетной обеспеченности регионов, не только выросла, усложнилась, но и стала менее прозрачной. В результате осуществленные реформы имели неоднозначные и различные последствия для субъектов Российской Федерации, особенно для национальных республик. По оценке исследователей, наиболее благоприятный режим в сфере получения субсидий и инвестиций из федерального бюджета распространялся на Татарстан, Чечню, Краснодарский край и Санкт-Петербург [11, с. 371].

В целом, по мнению экспертов, в новом столетии имела место серьезная неформальная трансформация конституционных принципов государственного устройства России, а именно: федеральное законодательство начало осуществлять переход от рамочного регулирования к унификации законодательства; соотношение полномочий по предметам совместного ведения стало изменяться в пользу Федерации; сократились перечень предметов остаточного ведения субъектов и объемы их регулирования; были созданы внеконституционные механизмы федерального вмешательства, а также внеконституционные государ- 
ственные органы для осуществления данной политики [14, с. 137].

Характеризуя особенности развития российского этнофедерализма, А. Захаров называет его «исполнительным», отмечая, что тип федеративного устройства, действующий в России, дает возможность правящим элитам заключать те или иные договоренности по основным направлениям национальной политики, фактически, во-первых, игнорируя нормы Конституции, во-вторых, исключая участие представительных органов власти, и в-третьих, без учета общественного мнения [8, с. 128].

Маятниковый характер отношений по линии «Федеральный центр - регионы», как представляется, обусловлен тем, что в России федерализм не воспринимается как форма гражданской самоорганизации и не имеет ценностного измерения как для элит Центра, так и для элит большинства регионов, что приводит к тому что он выступает в качестве механизма распределения и разделения власти [15, с. 103]. Однако федерация, лишенная ценностного измерения, нередко дает функциональные сбои. Поэтому очевидный «прагматизм» региональной политики Москвы плохо сочетается с несомненным признанием ценности федерализма и важности сохранения политической автономии элитами и «титульными этносами» национальных республик. Анализ экспертных интервью, проведенных в рамках исследования «Состояние и перспективы развития российского федерализма в массовом сознании и экспертных оценках», свидетельствует, что как на массовом уровне, так и на уровне элит сегодня нет понимания того, что такое федерализм. «Современное состояние их политического мировоззрения не предполагает ключевой составляющей федеративных отношений: федеративного торга, характеризуемого беспрерывной конкуренцией между центральной властью и регионами. Присущее им восприятие федеральных властей выказывает полное согласие с собственным второстепенным положением. В глазах большей части представителей региональных элит доминирование Москвы представляется естественным и нормальным. Наконец, за исключением представителей национальных республик, элиты в регионах не осознают значимости федерализма для сгла- живания межнациональных трений» [10, c. 312]. Как представляется, ситуации не поменяло и возвращение к контролируемой центром выборности губернаторов.

Баланс в отношениях между элитами центра и регионов определяется, прежде всего, по результатам постоянного торга и зависит от наличия и объема значимых ресурсов у сторон, ведущих такой торг, а также от готовности сторон вести его «по правилам». Политическая практика 2000-х гг. показала готовность Федерального центра менять «правила игры» по собственному усмотрению. В результате степень автономии «национальных» субъектов Федерации оказалась в полной зависимости от решений и действий Центра, что потенциально подрывает доверие национальных меньшинств к институтам федерализма.

Элиты национальных республик, которые в 1990-е гг. выступали «локомотивами суверенизации» (Татарстан, Башкортостан, Саха Якутия и др.), похоже, получили своего рода «охранную грамоту» и явно не утратили вкус к власти и ее неформальному перераспределению в свою пользу, конечно же, «во имя интересов своего народа». «В течение первого десятилетия XXI в. центру удавалось залить бюджетными деньгами все сколько-нибудь значимые финансовые и экономические проблемы регионов. В то же время последовательное сокращение поля, на котором может проявляться публичный протест, обеспечило видимость единства страны» [22, с. 89].

Тем не менее в условиях острого социально-экономического кризиса вновь может появиться мощная мотивация к поиску путей ослабления Федерального центра путем очередного перераспределения власти и ресурсов. Таким образом, не исключено возникновение угрозы сохранению целостности российского государства, которая, скорее всего, вновь будет исходить от национальных республик. Мы согласны с мнением, что «федерализм не долго будет оставаться спящим институтом: политическое размораживание делается все неизбежнее по мере медленного, неуклонного банкротства режима нефтяного изобилия, и скоро на него опять возникнет большой спрос» [9, с. 122]. Однако вопрос заключается в том, какие цели будут пре- 
следовать и какие ресурсы будут использовать центральные и региональные элиты в этой кризисной ситуации.

Политическая территориальная автономия этнических общностей, закрепленная Конституцией России, зачастую становится источником конфликтов и не способствует их разрешению. В целом же международный опыт свидетельствует, что, во-первых, случаи успешно работающих этнофедераций единичны, а большинство попыток их создания были не слишком удачными; во-вторых, при решении «этнической проблемы» наиболее успешные мультиэтничные западные демократии чаще идут не по пути предоставления национальным меньшинствам политической территориальной автономии, а по пути деполитизации этнического фактора, демонтажа институтов, связывающих этничность и власть, этничность и государство, что достигается за счет подчеркивания изменчивого, процессуального характера этнической идентичности и актуализации идеи «гражданской нации». Перечисленные обстоятельства не позволяют признать этнофедерализм наиболее оптимальным способом решения этнополитических проблем в «многонациональном» государстве. Сохранение этнической и религиозной принадлежности - это свободный выбор и неотъемлемое право каждого индивида, право оставаться самим собой, сохранять свою особую идентичность. Однако при этом люди должны подчиняться общим для всех правовым нормам, мирно сосуществовать, укреплять гражданскую солидарность во имя сохранения и процветания общего для них национального государства.

Как уже было отмечено, стабильность этнофедераций зависит от характера взаимоотношений элит Федерального центра и субъектов Федерации, понимания ими ценности и выгодности федерализма, непрерывности конкурентного торга. При этом понятна зависимость региональных элит от федеральной власти. Однако фактором поддержания нормальных отношений между сторонами является также зависимость Центра от поддержки регионов. В этой зависимости можно вычленить три составляющих. Во-первых, от региональных политических элит зависит эффективность и сама вероятность осуществления решений, которые принимаются федеральной властью. Во-вторых, эти элиты непосредственно ответственны за обеспечение стабильности в регионах. Они первыми сталкиваются с выражением недовольства населения и протестными выступлениями. В-третьих, речь идет и об «услугах», оказываемых федеральной власти региональными элитами. Прежде всего, это обеспечение «нужных» центру результатов в ходе федеральных выборов. Однако отношения между элитами центра и регионов в федерациях основаны на так называемом «неполном контракте» (incomplete contract), поскольку у такого контракта отсутствуют механизмы гарантий его исполнения. Иначе говоря, не существует внешней силы, которая могла бы принудить стороны выполнять взятые на себя институциональные обязательства. Таким образом, в силу дистрибутивного характера институционального выбоpa, политические решения, принимаемые представителями большинства, то есть правящей федеральной элиты, смещают правила в выгодную для них плоскость [26, с. 62].

Как утверждает сербский политолог В. Вуячич, имея в виду опыт СССР и СФРЮ: «Жизнеспособность этнотерриториального федерализма зависела от стабильной способности государства перераспределения, поддерживать определенные уровни развития, осуществлять перекачку средств, финансировать национальные учреждения культуры и удовлетворять ожидания этнического среднего класса в смысле социальной мобильности» [5, с. 32]. Однако эксперты отмечают неадекватность и неэффективность "реакции» российского Центра на «вызовы», идущие из регионов. Методы, используемые Центром для контроля над регионами в современной России, во многом повторяют имперскую модель покупки лояльности региональных элит, что требует больших финансовых затрат [4, c. 134]. Но если в период роста цен на энергоресурсы был возможен механизм перераспределения средств для поддержки локальных агентов Центра, то в условиях экономической рецессии, сопровождающей период пандемии и низкого потребительского спроса на нефть на мировых рынках, подобные механизмы, вероятнее всего, окажутся чересчур дорогостоящими и, как следствие, неэффективными. 
Политический опыт показывает, что эффективно руководить регионами из Центра просто невозможно, поэтому приходится делать ставку на региональные элиты и ужесточение контроля над ними. Однако в реальности правящие региональные элиты достаточно быстро становятся de facto автономными политическими субъектами, лишь формально выказывая лояльность центральной власти, что, в свою очередь, создает угрозу сохранению целостности страны. «Отсюда возникает парадокс фактической конфедерализации искусственно унитаризированного государства, в котором регионами управляют многочисленные локальные кланы и группы влияния, лишенные официального (конституционного) статуса», - отмечают либеральные критики режима [14, с. 138].

Ярким примером неформального перераспределения полномочий в пользу национального субъекта Федерации является Чечня, которая не требует пересмотра своего официального статуса, однако неуклонно наращивает объем своих исключительных полномочий: «Республика не выдвигает условий и не требует переговоров, но лишь использует удобные поводы для представления своей позиции не столько российскому или чеченскому обществам, сколько федеральному центру, являющемуся для нее единственным значимым партнером» [23, с. 64]. Одностороннее наращивание преференций и полномочий при молчаливом согласии Федерального центра исподволь подводит к изменению реального статуса данного региона.

Федеральный центр, ориентируясь на информацию, поступающую от фактически назначенных губернаторов, которые имеют мощную мотивацию ее приукрашивать, а также от неэффективного аппарата контролеров, вынужден реагировать на уже вызревшие и проявившиеся чрезвычайные ситуации, будь то массовые протесты или техногенные катастрофы, лишаясь возможности принимать упреждающие меры и в целом осуществлять эффективную региональную политику.

Альтернативой в российских условиях «является не классический федерализм американского типа и даже не более кооперативная, немецкая и австрийская версии, а асимметричная этническая федерация, в которой значительное дотирование (национальных) меньшинств по-прежнему необходимо. Однако по сравнению с империей, в работающей этнической федерации поддержание территориальной целостности обходится большинству все же намного дешевле. В такой федерации прямая покупка лояльности этнических элит отчасти заменяется перераспределением прав и прерогатив» [4, с. 134].

Но в связи с этим возникает, по меньшей мере, два трудных вопроса.

Во-первых, большинство этнофедераций на современном этапе исследователи чаще всего характеризуют либо как существующие в условиях «перманентного кризиса» (Канада, Нигерия, Эфиопия), либо в состоянии перманентного же перехода (Россия, Испания). При этом первым предсказывают перспективу распада, вторым же, напротив, грозит откат к унитаризму. Таким образом, обе категории государств не могут рассматриваться в качестве нормативного идеала этнического федерализма, что, в свою очередь, вызывает серьезные сомнения в возможности существования подобного идеала [12, с. 186-187].

Во-вторых, модель этнического федерализма намного сложнее модели имперской и для ее реализации требуется опыт, склонность к поиску компромиссов и политическая эффективность. Задача этнической региональной автономии - поддерживать баланс во взаимоотношениях акторов разного уровня, снижать конфликтный потенциал их взаимодействия, укрепляя систему обоюдных связывающих обязательств (credible commitments) [3, c. 8-9]. Однако откуда возьмутся ответственные и мудрые элиты и эффективные управленцы, способные обеспечить «работающую этническую федерацию» в России? Так, в рейтинге, составленном на основе использования нового индекса качества элит (разработан исследователями швейцарского университета Санкт-Галлена и Московской школы управления «Сколково»), Россия заняла 23-е место (из 32). Одной из главных проблем для российских элит назван низкий уровень доверия между государством, гражданами и бизнесом [18].

Если в 1990-е гг. всенародно избранные президенты и элиты республик в составе РФ «сумели “приручить” и канализировать агрес- 
сивный этнонационализм меньшинств, использовать его как ресурс в торге с федеральным центром за особый статус и экономические преференции, то сегодня, когда этот национализм глубоко пророс в ткань республиканских политических режимов, окреп интеллектуально и организационно, повторить это практически невозможно» [2, с. 315]. Фактически назначенные Центром главы исполнительной власти субъектов Федерации предпочитают встраиваться в «вертикаль власти» и подчиняться приказам, поступающим из Кремля, а не действовать в соответствии с интересами населения регионов, вряд ли справятся с этой сложной задачей. За последние три десятилетия, по утверждениям ряда экспертов, Россия совершила своего рода полный оборот, начиная с «парада суверенитетов» и широкой децентрализации конца 1980-х и начала 1990-х гг. до абсолютной централизации, вновь сталкиваясь с перспективой процессов децентрализации, с угрозой территориального распада государства [14, с. 138].

М. Фарукшин отмечает, что этнофедеративная система в принципе не предусматривает ни особых политических или экономических привилегий, ни дискриминации по этническому признаку [25, с. 149]. Однако, как отмечал еще сорок лет назад Б. Денич: «Чтобы успешно руководить многонациональным государством, во все времена требовалось, прежде всего, прибегать к ограничению или самоограничению доминантной этнической группы. Именно эта группа может стать угрозой для всего здания многоэтничности, если будет претендовать даже на те права, которыми уже располагают этнические меньшинства» [34, p. 318]. Именно на этом «добровольном самоограничении» этнического большинства строились не только советская и югославская, но и строится современная российская этнофедерация.

Результаты. Для обеспечения прав национальных меньшинств в этнофедерациях необходимо, прежде всего, найти решение ряда ключевых проблем. В первую очередь следует создать такие институциональные условия, действуя в рамках которых политические лидеры большинства будут заинтересованы в соблюдении интересов меньшинства. Далее должна развиться политическая прак- тика, при которой представители большинства не будут стремиться к изменению баланса как в свою пользу, так и в сторону большей унификации. Кроме того, меньшинство должно быть убеждено, что большинство волюнтаристски не изменит существующие правила. Осуществление этого комплекса задач представляется достаточно трудновыполнимым.

Для решения этих проблем, по мнению ряда исследователей, необходимо существование демократической конкурентной среды, в рамках которой доминируют политические партии, принявшие основные правила игры и заинтересованные в сохранении «асимметричного» федерализма [28; 30]. Однако в России сегодня нет таких политических партий. Все парламентские партии строятся на принципах «демократического централизма», все ключевые решения принимаются их руководством в Москве, а так называемая «партия власти» действует в условиях крайне слабой оппозиции, особенно в национальных республиках.

Очевидно, что межэтнические отношения следует выстраивать не исходя из некой идеальной модели, а отталкиваясь от существующей этнополитической реальности и используя имеющийся потенциал уже существующих несовершенных институтов этнофедерации. Сравнительный анализ существующих на данный момент этнических федераций демонстрирует сугубую специфичность развивающихся в каждой из них процессов, связанных с особенностями их становления, исторических традиций, характера межэтнических отношений, конфликтного потенциала отдельных регионов. Речь идет о необходимости дифференцированного подхода к анализу и оценке соотношения федерализма и этничности и основанных на этом выводах, в каких случаях учет этнического фактора в структуре Федерации крайне необходим, а в каких случаях он способен сыграть разрушительную роль. При этом важен учет и других влияющих на него факторов: прежде всего, степень демократичности государства, уровень его экономического и социального развития (особенно его «этнических регионов»), этнический состав общества и характер исторически сложившихся межэтнических отношений и т. д.

Следует признать, что, в отличие от русского большинства, для значительной части 
российских «национальностей» «роль институтов этнофедерализма в производстве и воспроизводстве этнической реальности столь же высока и значима, как и индивидуальное приписывание к этническим категориям (не случайно именно в национальных республиках в 1990-е гг. так активно протестовали против отмены пятой графы паспорта, фиксировавшей “национальность” индивида). ...Созданные новыми институтами субъекты социальной деятельности (титульные этносы. $-B$. $A$., $A$. A.) уже с трудом мыслят самих себя в отрыве от этих институтов, а сами социальные институты и практики рассматривают, скорее, как неизменную природу, нежели как продукт усилий нескольких предшествовавших поколений» $[20$, с. $60-61,75]$.

В связи с этим уже не раз сформулированные предложения по созданию равноправных в правовом и экономическом плане новых субъектов Федерации, развивающихся в едином темпе, и постепенная симметризация федеративной структуры [7, с. 92], или полный отказ от принципов федерализма (В.В. Жириновский) могут рассматриваться в качестве наименее вероятной для России перспективы. Можно согласиться с мнением В.А. Тишкова, что «ликвидацию или радикальную реформу российских республик практически невозможно осуществить. История северокавказских этнотерриториальных образований (и не только их. $-B$. $A$., $A$. $A$.) уже породила целую систему институтов второго уровня, которые существуют в сфере правовой и хозяйственной практики, образовательно-культурного производства, местного самосознания и патриотизма» [24, c. 9]. Поэтому необходима не радикальная смена институтов российского этнического федерализма, а совершенствование системы регионального управления в сторону ее большей представительности, демократизма, эффективности и прозрачности.

\section{ПРИМЕЧАНИЕ}

1 Данное исследование выполнено в рамках гранта Российского фонда фундаментальных исследований № 20-011-31077 «Этнополитические конфликты в современном мире: постсоветский контекст» 2020 года.
This research was carried out within the framework of the grant of the Russian Foundation for Basic Research No. 20-011-31077 “Ethnopolitical conflicts in the modern world: the post-Soviet context" 2020.

\section{СПИСОК ЛИТЕРАТУРЫ}

1. Ачкасов, В. А. Конфликтный потенциал этнофедерализма / В. А. Ачкасов // ПОЛИТЭКС: Политическая экспертиза. - 2008. - Т. 4, № 2. - С. 27-43.

2. Ачкасов, В. А. Российская дилемма: империя или нация-государство / В. А. Ачкасов. - М. : Юрайт, 2019. - 373 с.

3. Балансируя притязания: этнические региональные автономии, целостность государства и права этнических меньшинств / под ред. П. В. Панова. - М. : РОССПЭН, 2017. - 213 с.

4. Бусыгина, И. Проблемы вынужденной федерализации / И. Бусыгина, М. Филлипов // Pro et Contra. - 2009. - Т. 13, № 3-4 (46), май - август. C. $125-138$.

5. Вуячич, В. Национализм, миф и государство в России и Сербии: Предпосылки распада СССР и Югославии / В. Вуячич. - СПб. : Изд-во Европ. ун-та в Санкт-Петербурге, 2019. - 480 с.

6. Выступление президента РФ В.В. Путина на заседании Правительства РФ с участием глав региональных администраций, Москва, 13 сент. 2004 г. Электрон. текстовые дан. - Режим доступа: http:// kremlin.ru/text/appears/2004/09/76651.html. (дата обращения: 13.08.2020). - Загл. с экрана.

7. Доктрина регионального развития Российской Федерации : мини-проект / под ред. А. С. Малчинова. - М. : Научный эксперт, 2009. - 256 с.

8. Захаров, А. А. «Исполнительный федерализм» в современной России / А. А. Захаров // Полис. Политические исследования. - 2011. - № 4. C. 122-131.

9. Захаров, А. А. «Спящий институг»: Федерализм в современной России и в мире / А. А. Захаров. М. : Новое литературное обозрение, 2012. - 134 с.

10. Захаров, А. А. «Имперский синдром»: о восприятии федерализма представителями региональных элит. К новой модели российского федерализма / А. А. Захаров ; под общ. ред. А. Рябова, А. Захарова [и др.]. - М. : Весь мир, 2013. - С. 303-314.

11. Зубаревич, Н. Общество и элиты в российских регионах: изменения в постсоветский период. Четверть века после СССР: люди, общество, реформы / Н. Зубаревич ; под ред. Е. Б. Шестопал, А. Ю. Шугова [и др.]. - М. : Изд-во Моск. ун-та, 2015. - 464 с.

12. Ильченко, М. С. Федеративные механизмы в разрешении этнических конфликтов: переговорный процесс в рамках формальных правил / М. С. Ильченко // Политическая наука. - 2011. - № 1. - С. 170-190. 
13. Конституционно-правовые проблемы развития российского федерализма / под ред. Л. А. Иванченко. - М. : Изд. Гос. Думы, 2000. - 191 с.

14. Лукьянова, Е. Авторитаризм и демократия / Е. Лукьянова, И. Шаблинский. - М. : Мысль, 2018. $348 \mathrm{c}$.

15. Миронюк, М. Г. Современный федерализм: Сравнительный анализ / М. Г. Миронюк. М. : РОССПЭН, 2008. -279 с.

16. Осипов, А. Эссенциалистские представления об этничности в системах преподавания правовых специальностей. Расизм в языке образования / А. Осипов ; под ред. В. Воронкова, О. Карпенко [и др.]. - СПб. : Алетейя, 2008. - С. 140-167.

17. Петров, Н. В. Федерализм по-российски / Н. В. Петров // Pro et Contra. - 2000. - T. 5, № 1. C. 7-33.

18. Россия заняла 23-е место в новом рейтинге качества элит. - Электрон. текстовые дан. - Режим доступа: https://www.vedomosti.ru/economics/news/ 2020/09/03/838665-rossiya-zanyala-23-e-mesto?utm source=yxnews\&utm_medium=desktop (дата обращения: 5.08.2020). - Загл. с экрана.

19. Сидоренко, А. В. Федерализм в мультиэтническом обществе: проблемы и перспективы / А. В. Сидоренко. - СПб. : Изд-во РГПУ им А.И. Герцена, 2008. $-236 \mathrm{c}$.

20. Соколовский, С. В. Перспективы развития концепции этнонациональной политики в Российской Федерации / С. В. Соколовский. - М. : Привет, 2004.-257 c.

21. Стародубцев, А. «Прыжок вниз»: научные дискуссии и политическая практика децентрализации. Пути модернизации: траектории, развилки и тупики : сб. ст. / А. Стародубцев ; под ред. В. Гельмана, О. Маргания. - СПб. : Изд-во Европ. ун-та в Санкт-Петербурге, 2010. - С. 89-110.

22. Стародубцев, А. Бесполезное достижение? Губернаторские выборы в контексте проблем регионального развития / А. Стародубцев // Неприкосновенный запас. - 2012. - № 4. - С. 82-90.

23. Стародубцев, А. Пересмотр федеративного контракта в России: случай Чеченской Республики / А. Стародубцев // Неприкосновенный запас. 2017. - № 1. - С. 59-67.

24. Тишков, В. А. Введение/ В. А. Тишков // Конфликтологические модели и мониторинг конфликтов в Северо-Кавказском регионе / М. А. Аствацатурова, В. А. Тишков, Л. Л. Хоперская. - М. : ФГНУ «Росинформагротех», 2010. - С. 4-9.

25. Фарукшин, М. Х. Этничность и федерализм / М. Х. Фарукшин. - Казань : Центр инновационных технологий, 2013. -348 с.

26. Филиппов, М. Федерализм, демократия и проблема «добросовестных обязательств» в отношении этнических меньшинств / М. Филиппов
// Федерализм и этническое разнообразие в России : сб. ст. / под ред. И. Бусыгиной, А. ХайнеманнГрюдера. -М. : РОССПЭН, 2010. - С. 60-79.

27. Шабаев, Ю. П. Исторические корни современного финно-угорского паннационализма / Ю. П. Шабаев // Вопросы этнополитики. - 2018. № 1 (1). - C. 38-54.

28. Aghion, $\mathrm{Ph}$. Incomplete Social Contract / $\mathrm{Ph}$. Aghion, P. Bolton // Journal of the European Economic Association. - 2003. - № 1. - P. 38-67.

29. Basta, K. The State as a Symbol or a Means to an End: Internal Border Changes in Multinational Federations / K. Basta // Nations and Nationalism. 2014. - Vol. 20, № 3. - P. 459-480. - DOI: https://doi.org/ 10.1111/nana.12050.

30. Bednar, J. The Robust Federation: Principles of Design / J. Bednar. - Cambridge : Cambridge University Press, 2009. - 242 p.

31. Bunce, V. Subversive Institutions: The Design and Destruction of Socialism and the State / V. Bunce. - Cambridge : Cambridge University Press, 1999. - P. 77-102.

32. Burgess, M. Comparative Federalism: Theory and practice / M. Burgess. - New York : Routledge, 2006. $-357 \mathrm{p}$.

33. Caron, J.-F. Canada and Multinational Federalism: From the Spirit of 1982 to Stephen Harper's Open Federalism / J.-F. Caron, G. Laforest // Nationalism and Ethnic Politics. - 2009. - Vol. 15, № 1. - P. 27-55.

34. Denitch, B. Dilemma of the Dominant Ethnic Group / B. Denitch // Ethnic Russia in the USSR: The Dilemma of Dominance / ed. by E. Alworth. - New York : Pergamon Press, 1980. - P. 315-325.

35. Erk, J. The Paradox of Federalism: Does SelfRule Accommodate or Exacerbate Ethnic Divisions? / J. Erk, L. Anderson. - London ; New York : Routledge, 2010. -140 p.

36. Federalism: Choices in Law, Institutions and Policy: A Comparative Approach with Focus on the Russian Federation / ed. by K. Malfliet. - Leuven (Belgium) : Garant Publishers, 1998. - 230 p.

37. Hale, H. E. Divided We Stand. Institutional Sources of Ethnofederal States Survival and Collapse / H. E. Hale // World Politics. - 2004. - Vol. 56, № 2. P. 165-193.-DOI: https://doi.org/10.1353/wp.2004.0011.

38. Kymlika, W. Federalism, Nationalism and Multiculturalism in Theories of Federalism: A Reader / W. Kymlika ; ed. by D. Karmis, W. Norman. - N. Y. : Palgrave Macmillan, 2005. - P. 269-292.

39. McGarry, J. Can Federalism Help to Manage Ethnic and National Diversity? / J. McGarry // Federations. - 2005. - Vol. 5, № A-1. - P. 15-17. Electronic text data. - Mode of access: http:// www.forumfed.org/libdocs/Federations/V5N1SEenint-McGarry.pdf (date of access: 15.08.2020). - Title from screen. 
40. McGarry, J. Federation as a Method of Ethnic Conflict Regulation / J. McGarry, B. O'Leary. - Electronic text data. - Mode of access: www.forumfed.org (date of access: 16.08.2020). - Title from screen.

41. Stoner-Weiss, K. Resistance to the Central State on the Periphery. The State After Communism / K. Stoner-Weiss ; ed. by T. Colton and St. Holmes. New York : Rowman \& Littlefield, 2006. - P. 86-98.

42. Van Ginderachter, M. Denied ethnicism: on the Walloon movement in Belgium / M. Van Ginderachter, J. Leerssen // Nations and Nationalism. 2012. - Vol. 18, № 2. - P. 228-241.

\section{REFERENCES}

1. Achkasov V.A. Konfliktnyj potencial jetnofederalizma [The Conflict Potential of Ethnic Federalism]. POLITJeKS: Politicheskaja jekspertiza [Political expertise: POLITEX], 2008, vol. 4, no. 2,pp. $27-43$.

2. Achkasov V.A. Rossijskaya dilemma: imperiya ili naciya-gosudarstvo [Russian Dilemma: Empire or Nation State]. Moscow, Yurayt Publ., 2019. $373 \mathrm{p}$.

3. Panov P.V., ed. Balansiruja pritjazanija: jetnicheskie regionalnye avtonomii, celostnost gosudarstva i prava jetnicheskih menshinstv [Balancing Claims: Ethnic Regional Autonomies, State Integrity, and the Rights of Ethnic Minorities]. Moscow, ROSSPEN Publ., 2017. 213 p.

4. Busygina I., Filippov M. Problemy vynuzhdennoj federalizacii [Problems of Forced Federalization]. Pro et Contra, 2009, vol. 13, no. 3-4 (46), May-August, pp. 125-138.

5. Vujachich V. Nacionalizm, mifi gosudarstvo $v$ Rossii i Serbii: Predposylki raspada SSSR i Jugoslavii [Nationalism, Myth and State in Russia and Serbia: Preconditions for the Collapse of the USSR and Yugoslavia]. Saint Petersburg, Izd-vo Evropejskogo universiteta v Sankt-Peterburge, 2019.480 p.

6. Vystuplenie prezidenta RF V.V. Putina na zasedanii Pravitelstva RF $s$ uchastiem glav regionalnyh administracij [Speech by Russian President Vladimir Putin at a Meeting of the Russian Government with the Participation of the Heads of Regional Administrations]. Moscow, September 13, 2004. URL: http://kremlin.ru/text/appears/2004/09/ 76651.html (accessed 15 August 2020).

7. Malchinova A.S., ed. Doktrina regionalnogo razvitija Rossijskoj Federacii: mini-proekt [Regional Development Doctrine of the Russian Federation: Mini Project]. Moscow, Nauchnyj jekspert Publ., 2009. 256 p.

8. Zaharov A.A. «Ispolnitelnyj federalizm»v sovremennoj Rossii ["Executive Federalism" in Contemporary Russia]. Polis. Politicheskie issledovanija [Polis. Political Studies]. 2011, no. 4, pp. 122-131.
9. Zaharov A.A. "Spjashhij institut»: Federalizm v sovremennoj Rossii $i$ v mire [The Sleeping Institute: Federalism in Contemporary Russia and the World]. Moscow, Novoe literaturnoe obozrenie Publ., 2012. $134 \mathrm{p}$.

10. Zaharov A.A., Rjabov A. ed. "Imperskij sindrom»: o vosprijatii federalizma predstaviteljami regionalnyh jelit. $K$ novoj modeli rossijskogo federalizma ["Imperial Syndrome": How Federalism is Perceived by Representatives of the Russian Regional Elites. Toward a New Model of Russian Federalism]. Moscow, Ves mir Publ., 2013, pp. 303-314.

11. Zubarevich N., Shestopal E.B., Shutova A.Ju. eds. Obshhestvo $i$ jelity $v$ rossijskih regionah: izmenenija $v$ postsovetskij period. Chetvert veka posle SSSR: ljudi, obshhestvo, reformy [Society and Elites in Russian Regions: Changes in the Post-Soviet Period. A Quarter of a Century after the USSR: People, Society, Reforms]. Moscow, Izd-vo Moskovskogo universiteta, 2015. 464 p.

12. Ilchenko M.S. Federativnye mehanizmy v razreshenii jetnicheskih konfliktov: peregovornyj process $\mathrm{v}$ ramkah formalnyh pravil [Federative Mechanisms in the Resolution of Ethnic Conflicts: The Negotiation Process Within the Framework of Formal Rules]. Politicheskaja nauka [Political Science], 2011, no. 1, pp. 170-190.

13. Ivanchenko L.A., ed. Konstitucionnopravovye problemy razvitija rossijskogo federalizma [Constitutional and Legal Problems of the Russian Federalism Development]. Moscow, Izdanie Gosudarstvennoj Dumy, 2000. 191 p.

14. Lukjanova E., Shablinskij I. Avtoritarizm $i$ demokratija [Authoritarianism and Democracy]. Moscow, Mysl Publ., 2018. 348 p.

15. Mironjuk M.G. Sovremennyj federalizm: Sravnitelnyj analiz [Modern Federalism: A Comparative Analysis]. Moscow, ROSSPEN Publ., 2008. 279 p.

16. Osipov A., Voronkov V., Karpenko O., eds. Jessencialistskie predstavlenija ob jetnichnosti $v$ sistemah prepodavanija pravovyh specialnostej. Rasizm v jazyke obrazovanija [Essentialist Ideas About Ethnicity in the Systems of Teaching Legal Specialties. Racism in the Language of Education]. Saint Petersburg, Aletheia Publ., 2008, pp. 140-167.

17. Petrov N.V. Federalizm po-rossijski [Federalism a La Russe]. Pro et Contra, 2000, vol. 5, no. 1, pp. 7-33.

18. Rossiya zanyala 23-e mesto $v$ novom rejtinge kachestva elit [Russia Took 23rd Place in the New Rating of the Quality of Elites]. URL: https:// www.vedomosti.ru/economics/news/2020/09/03/ 838665-rossiya-zanyala-23-e-mesto?utm_source= yxnews\&utm_medium $=$ desktop (accessed 5 August 2020). 
19. Sidorenko A.V. Federalizm v multijetnicheskom obshhestve: problemy i perspektivy [Federalism in a Multi-Ethnic Society: Problems and Prospects]. Saint Petersburg, Izd-vo RGPU im A.I. Gercena, 2008. 236 p.

20. Sokolovskij S.V. Perspektivy razvitija koncepcii jetnonacionalnoj politiki v Rossijskoj Federacii [Prospects for the Development of the Concept of Ethno-National Policy in the Russian Federation]. Moscow, Privet Publ., 2004. 257 p.

21. Starodubcev A., Gelman V., Marganija O., eds. «Pryzhok vniz»: nauchnye diskussii i politicheskaja praktika decentralizacii. Puti modernizacii: traektorii, razvilki i tupiki: sb. st. ["Leap Down": Scholarly Debate and Policy Practice for Decentralization. Modernization Paths: Trajectories, Forks and Dead Ends. Collection of Articles]. Saint Petersburg, Izd-vo Evropejskogo universiteta v SanktPeterburge, 2010, pp. 89-110.

22. Starodubcev A. Bespoleznoe dostizhenie? Gubernatorskie vybory v kontekste problem regionalnogo razvitija [Useless Achievement? Governor Elections in the Context of Regional Development Problems]. Neprikosnovennyj zapas, 2012, no. 4, pp. 82-90.

23. Starodubcev A. Peresmotr federativnogo kontrakta v Rossii: sluchaj Chechenskoj Respubliki [Revision of the Federal Contract in Russia: The Case of the Chechen Republic]. Neprikosnovennyj zapas, 2017, no. 1, pp. 59-67.

24. Tishkov V.A., Astvatsaturova M. A., Khoperskaya L. L. Konfliktologicheskie modeli $i$ monitoring konfliktov $v$ Severo-Kavkazskom regione [Conflict Models and Conflicts Monitoring in the North Caucasus Region]. Moscow, FGNU «Rosinformagroteh», 2010, pp. 4-9.

25. Farukshin M.H. Jetnichnost i federalizm [Ethnicity and Federalism]. Kazan, Centr innovacionnyh tehnologij, 2013. $348 \mathrm{p}$.

26. Filippov M., Busygina I., HajnemannGrjuder A., eds. Federalizm, demokratija i problema "dobrosovestnyh objazatelstv» v otnoshenii jetnicheskih menshinstv. Federalizm i jetnicheskoe raznoobrazie $v$ Rossii [Federalism, Democracy and the Problem of "Good Faith Commitment" to Ethnic Minorities. Federalism and Ethnic Diversity in Russia]. Moscow, ROSSPEN Publ., 2010, pp. 60-79.

27. Shabaev Ju.P. Istoricheskie korni sovremennogo finno-ugorskogo pannacionalizma [Historical Roots of Modern Finno-Ugric Pannationalism]. Voprosy jetnopolitiki [Issues of ethnopolitics], 2018, no. 1 (1), pp. 38-54.

28. Aghion Ph., Bolton P. Incomplete Social Contract. Journal of the European Economic Association, 2003, no. 1, pp. 38-67.
29. Basta K. The State as a Symbol or a Means to an End: Internal Border Changes in Multinational Federations. Nations and Nationalism, 2014, vol. 20, no. 3,pp. 459-480. DOI: https://doi.org/10.1111/ nana. 12050.

30. Bednar J. The Robust Federation: Principles of Design. Cambridge, Cambridge University Press, 2009. $242 \mathrm{p}$.

31. Bunce V. Subversive Institutions: The Design and Destruction of Socialism and the State. Cambridge, Cambridge University Press, 1999, pp. 77-102.

32. Burgess M. Comparative Federalism: Theory and Practice. New York, Routledge, 2006. 357 p.

33. Caron J.-F., Laforest G. Canada and Multinational Federalism: From the Spirit of 1982 to Stephen Harpers Open Federalism. Nationalism and Ethnic Politics, 2009, vol. 15, no. 1, pp. 47-64.

34. Denitch B. Dilemma of the Dominant Ethnic Group. Alworth E., ed. Ethnic Russia in the USSR: The Dilemma of Dominance. New York, Pergamon Press, 1980, pp. 315-325.

35. Erk J., Anderson L. The Paradox of Federalism: Does Self-Rule Accommodate or Exacerbate Ethnic Divisions? London; New York, Routledge, 2010. $140 \mathrm{p}$.

36. Malfliet K., ed. Federalism: Choices in Law, Institutions and Policy: A Comparative Approach with Focus on the Russian Federation. Leuven, Garant Publishers, 1998. $230 \mathrm{p}$.

37. Hale H.E. Divided We Stand. Institutional Sources of Ethnofederal States Survival and Collapse. World Politics, 2004, vol. 56, no. 2, pp. 165-193. DOI: https://doi.org/10.1353/wp.2004.0011.

38. Kymlika W., Karmis D., Norman W., eds. Federalism, Nationalism and Multiculturalism. Theories of Federalism: A Reader. New York, Palgrave Macmillan, 2005, pp. 269-292.

39. McGarry J. Can Federalism Help to Manage Ethnic and National Diversity? Federations, 2005, vol. 5, no. A-1, pp. 15-17. URL: http://www.forumfed. org/libdocs/Federations/V5N1SEen-int-McGarry.pdf (accessed 15 August 2020).

40. McGarry J., OLeary B. Federation as a Method of Ethnic Conflict Regulation. URL: www.forumfed.org (accessed 16 August 2020).

41. Stoner-Weiss K., Colton T., Holmes St., eds. Resistance to the Central State on the Periphery. The State After Communism. New York, Rowman \& Littlefield, 2006, pp. 86-98.

42. Van Ginderachter M., Leerssen J. Denied Ethnicism: On the Walloon Movement in Belgium. Nations and Nationalism, 2012, vol. 18, no. 2, pp. 228-241. 


\section{ИНСТИТУЦИОНАЛИЗАЦИЯ РЕГИОНАЛЬНОГО ПРОСТРАНСТВА РФ}

\section{Information About the Authors}

Valery A. Achkasov, Doctor of Sciences (Politics), Professor, Head of the Department of Ethnic Politics, Saint Petersburg State University, Universitetskaya emb., 7/9, 196034 Saint Petersburg, Russian Federation, v.achkasov@spbu.ru, https://orcid.org/0000-0002-9404-6100

Anna I. Abalian, Candidate of Sciences (Politics), Associate Professor, Department of Ethnic Politics, Saint Petersburg State University, Universitetskaya emb., 7/9, 196034 Saint Petersburg, Russian Federation, a.abalyan@spbu.ru, https://orcid.org/0000-0002-5171-2361

\section{Информация об авторах}

Валерий Алексеевич Ачкасов, доктор политических наук, профессор, заведующий кафедрой этнополитологии, Санкт-Петербургский государственный университет, Университетская набережная, 7/9, 196034 г. Санкт-Петербург, Российская Федерация, v.achkasov@spbu.ru, https://orcid.org/0000-0002-9404-6100

Анна Игоревна Абалян, кандидат политических наук, доцент кафедры этнополитологии, Санкт-Петербургский государственный университет, Университетская набережная, 7/9, 196034 г. Санкт-Петербург, Российская Федерация, a.abalyan@spbu.ru, https://orcid.org/0000-0002-5171-2361 